Article

\title{
The Association of Typhoon Intensity Increase with Translation Speed Increase in the South China Sea
}

\author{
Ya-Ting Chang, I-I Lin *, Hsiao-Ching Huang $®$, Yi-Chun Liao and Chun-Chi Lien $(\mathbb{0}$ \\ Department of Atmospheric Sciences, National Taiwan University, Taipei 10617, Taiwan; \\ ytchang17@ntu.edu.tw (Y.-T.C.); hchuang@as.ntu.edu.tw (H.-C.H.); d06229001@g.ntu.edu.tw (Y.-C.L.); \\ mglien@as.ntu.edu.tw (C.-C.L.) \\ * Correspondence: iilin@as.ntu.edu.tw
}

Received: 10 October 2019; Accepted: 22 January 2020; Published: 27 January 2020

\begin{abstract}
Tropical cyclone (TC) translation speed is an important parameter. In the context of TC-ocean interaction, faster translation speed can contribute to less TC-induced ocean cooling and thus enables more air-sea enthalpy flux supply to favor TC intensification. In 2018, Kossin published an interesting paper in Nature, reporting a global slow-down of TC translation speed since the 1950s. However, upon close inspection, in the last two decades, TC translation speed actually increased over the western North Pacific (WNP) and neighboring seas. Thus, we are interested to see which sub-region in the WNP and neighboring seas had the largest increase during the last two decades, and whether such increases contribute to TC intensification. Our results found statistically significant translation speed increases $\left(\sim 0.8 \mathrm{~ms}^{-1}\right.$ per decade) over the South China Sea. Ruling out other possible factors that may influence TC intensity (i.e., changes in atmospheric vertical wind shear, pre-TC sea surface temperature or subsurface thermal condition), we suggest, in this research, the possible contribution of TC translation speed increases to the observed TC intensity increases over the South China Sea in the last two decades (1998-2017).
\end{abstract}

Keywords: tropical cyclone; translation speed; TC-ocean interaction

\section{Introduction}

Tropical cyclone translation speed (Uh) is an important TC attribute. The slowing-down of Uh (e.g., the case of Typhoon Morakot in Taiwan in 2009 and Hurricane Harvey in the US in 2017) can increase hazards over land due to the longer impact time [1-3]. Over the ocean, $\mathrm{Uh}$ is an important parameter that influences TC-ocean interaction [4-9]. The faster the Uh, the smaller the TC-induced ocean cooling effect, and the more air-sea enthalpy flux is available for TC intensification [4,7,10-18].

In 2018, Kossin published an intriguing paper in Nature [2], suggesting a long-term (1949-2016) trend of slowing tropical cyclone (TC) translation speed over global oceans. Upon careful inspection with Kossin's time series (Figure 1a,b), despite the long-term trend of slowing since 1949, Uh in the most recent period is actually increasing (from the late 90s/early 00s). This is especially noticeable over the WNP and neighboring seas (light blue line in Figure 1b). In this research, we would like to explore this recent trend of increasing Uh over the WNP and neighboring seas, the associated TC-ocean interaction, and the possible impact on TC intensity. The reason for focusing on this most recent period (1998-2017) is also due to the data quality, since the data quality from the earlier period is not as reliable [19-22]. Also, 1998 is a meaningful year in the WNP, as PDO (Pacific decadal oscillation) also changed from the warm phase to the cold phase [23-25]. Therefore, starting from 1998 ensures that all analyses are performed within the same multi-decadal phase without introducing further complications. 
Due to our geographical location over Asia, we are primarily interested in TCs (i.e., typhoons) over the western North Pacific (WNP) and the neighboring East China Sea (ECS) and South China Sea (SCS) (Figure 2) [23-39].

To ensure accuracy and robustness, we reproduced Kossin's global trend, before zooming into the WNP and neighboring seas. After the successful reproduction of Kossin's trend (light blue curve in Figure 1c, location in Figure 2), we proceeded to check Uh trends over the WNP, ECS, and SCS (Figure 3). As will be shown, because the SCS experienced the most robust and evident Uh increase, this research is largely focused on the SCS.

\section{Data and Methods}

The TC track and intensity data (six hourly) is from the best-track dataset from the US Joint Typhoon Warning Center (JTWC, https://www.metoc.navy.mil/jtwc/jtwc.html). Typhoon season is defined as being from July to October. To exclude the influence of land, the SCS domain is $105-120^{\circ} \mathrm{E}$ and $5-25^{\circ} \mathrm{N}$ (Figure 2). Sea surface temperature (SST) and upper ocean thermal structure (UOTS) data is from the European Centre for Medium-Range Weather Forecasts (ECMWF)'s ORAS4 (Ocean ReAnalysis System 4, https://www.ecmwf.int/en/research/climate-reanalysis/ocean-reanalysis) monthly reanalysis data [40]. The horizontal resolution is $1^{\circ}$ with 42 vertically levels (17 levels in the upper $200 \mathrm{~m}$ of the ocean). Only grids with a depth greater than $200 \mathrm{~m}$ are used for analysis.

Oceans not only supply energy (i.e., air-sea fluxes) to TCs but also are stirred by TCs' strong winds. The drag between air and water accelerates the ocean current. Stratified oceans respond with vertical current shear, which break upper ocean stratification and mix with the cooler water underneath [4]. SST would be lowered after such mixing and, hence, reduce the air-sea flux supply from the ocean for TC intensification [11,16,41-43]. This is the well-known self-induced ocean cooling negative feedback for TC intensification. The magnitude of this self-induced cooling effect is related to a TC's strength (i.e., intensity in wind speed), translation speed, size, and oceanic pre-condition $[4,14,15,17,41,42,44-51]$. Larger and stronger TCs could induce more cooling than smaller, weaker ones [4,48]. For the oceanic pre-condition, a deeper pre-existing ocean mixed layer and depth of the $26{ }^{\circ} \mathrm{C}$ isotherm (D26) and a higher upper ocean heat content (or called tropical cyclone heat potential, i.e., heat content integrated from sea surface to D26) can effectively limit the self-induced cooling effect and favor TC intensification $[7,41,42,44,45]$. Inversely, a thinner mixed layer could result in stronger self-induced TC cooling $[5,6,29,49,52-54]$. Slower-moving TCs can induce a more symmetrical, larger amplitude of cooling $[5,6,29,55,56]$ than faster TCs, while reducing the TC's intensity $[49,57]$.

Based on the above, SST under TCs (i.e., during-TC SST-in other words, the SST includes the cooling effect, i.e., the actual SST during TC-ocean interaction) is crucial to the TC's intensity. To estimate during-TC SST (i.e., pre-TC SST minus TC's self-induced ocean cooling), we employed the latest model from Price (2009) [58]. As in Price (2009) [58], the performance of this new model is comparable to the classic 3DPWP model [10,59], but can be run more efficiently. The inputs are pre-TC temperature and salinity profiles, TC's maximum sustained wind speed, translation speed and radius of maximum wind (RMW). The model estimates the depth of mixing via bulk Richardson number between oceanic layers $[4,58,59]$. The bulk Richardson number $(R i)$ was defined as

$$
R i=\frac{g \delta \rho d}{\rho_{0}(\delta U)^{2}}
$$

where $g$ is the acceleration of gravity, $d$ is the layer thickness, and $\rho_{0}$ is the density of surface. $\delta \rho$ and $\delta U$ are the difference of density and wind-driven current velocity between the surface layer and the layer just below. When $R i$ was less than 0.65 , the surface mixed layer was mixed with the layer below it and the temperature was calculated via (2). When $R i$ was equal to or larger than 0.65 , the mixing was terminated. Once the mixing depth was estimated, depth-average temperature from SST to the 
new mixing depth (i.e., during-TC SST, i.e., $T_{\text {mix }}$, the SST mixed by the intense TC wind) was obtained as below:

$$
T_{\text {mix }}=\frac{1}{d} \int_{-d}^{0} T_{i}(z) d z
$$

where $d$ is the TC-induced mixing depth. For this simplified 1D model, there is an adjusting factor, $\mathrm{S}$, allowing the resulting $\mathrm{T}_{\mathrm{mix}}$ at any position across TC's track. For the case of Hurricane Frances (2004), $\mathrm{S}$ was set as 1.2 at $55 \mathrm{~km}$ right of TC's center and 0.4 at $55 \mathrm{~km}$ left of TC's center [56]. Considering TC actually felt temperature over an area (e.g., radius of $70 \mathrm{~km}$ to TC's center in Huang et al. (2015) [50]), $\mathrm{S}$ was set as 0.6 here.

For the input in this research, UOTS was from EMCWF's ORAS4, TC's translation speed and maximum sustained wind speed were the TC-season average data from JTWC (i.e., Figures $3 \mathrm{~b}$ and 4 ). Because JTWC does not have size information for the entire period, for RMW, we adopted the concept of nondimensional storm speed proposed by Price (1981) [4] (also in D'Asaro et al. 2014 [17]). The nondimensional storm speed is defined as,

$$
\frac{U h}{2 f R M W}
$$

where $f$ is the Coriolis parameter. If a TC's transit time $\left(\frac{2 R M W}{U h}\right)$ was comparable to the local inertial period, the oceanic response would be resonant. A average translation speed in TC season in the SCS $\left(4.31 \mathrm{~ms}^{-1}\right)$ was obtained from JTWC. As the average latitude for our research domain was $15^{\circ} \mathrm{N}$, the representative RMW can thus be calculated as

$$
R M W=\frac{U h}{2 f}
$$

Here, $R M W$ was set as $57 \mathrm{~km}$.

After during-TC SST estimation as above, the air-sea enthalpy (i.e., latent + sensible heat) flux was calculated using the bulk aerodynamic formula under high wind conditions as below $[13,15,16,18]$.

$$
\text { SHF : } Q_{s}=C_{H} W\left(T_{m i x}-T_{a}\right) \rho_{a} C_{p a} \text { LHF }: Q_{L}=C_{E} W\left(q_{s}-q_{a}\right) \rho_{a} L_{v a}
$$

where $C_{H}$ and $C_{E}$ are the sensible and latent heat exchange coefficients, respectively, $W$ is ocean surface wind speed, $T_{m i x}$ and $T_{a}$ are during-TC SST and near surface air temperature, respectively, $q_{s}$ and $q_{a}$ are surface and air specific humidity, respectively, and $\rho_{a}, C_{p a}$, and $L_{v a}$ are air density, heat capacity of the air, and latent heat of vaporization, respectively. Here the $T_{a}$ and $q_{a}$ data were from the climatological average data (TC season over the study period and the study domain) from the monthly ECMWF Interim atmospheric re-analysis data ( $1^{\circ}$ horizontal resolution).

Finally, atmospheric vertical wind shear (VWS) was calculated based on the 200 and $850 \mathrm{hPa}$ wind difference, using the monthly ECMWF atmospheric reanalysis data ( $1^{\circ}$ horizontal resolution). It was also necessary to examine VWS, as TC intensification is governed by both atmospheric and oceanic factors $[12,60-62]$.

\section{Results}

\subsection{Comparison Between Uh in the WNP, ECS, and SCS}

We first explored whether the global trend of increasing Uh from Kossin (2018) [2] can also be found all over the WNP and its neighboring regions. To ensure accuracy and robustness, we reproduced Kossin's WNP trend, before zooming into the Asian sub-regions. The track data were from JTWC and the area was set as $100-180^{\circ} \mathrm{E}$ and $0-50^{\circ} \mathrm{N}$ (Figure 2). Data were included from the entire year. The translation speed was calculated with central difference. Three six-hour TC positions were included in each calculation. The translation speed was calculated with the first and third position and 
the value fell on the second position. With the central difference calculation, the translation speed could be estimated for each TC, but the value of the beginning and endpoint of each TC would be excluded.

The light blue line in Figure 1c is depicted from the light blue line in Figure 1b, the annual average translation speed in the WNP from Kossin (2018). The red line is our reproduction. As can be seen, both lines are closely matched, showing successful reproduction. To further confirm this, we calculated the linear trend from 1949 to 2016. The result is $-0.05 \mathrm{~km} \mathrm{~h}^{-1}$ year $^{-1}$ with a $p$-value of $3.06 \mathrm{e}^{-7}$, which is the same value as in Kossin (2018) (Extended Data Table 1). It should also be noted that, in Figure 1c, though the trend from 1949 to 2016 was decreasing, we can also find an increasing trend in the recent period. Using the updated data, we estimated that the new trend lasted from 1998 to 2017 . The translation speed of TCs was $+0.14 \mathrm{~km} \mathrm{~h}^{-1}$ year $^{-1}(p=0.026,>95 \%)$, indicating that TCs increased their moving speed over the past 20 years.
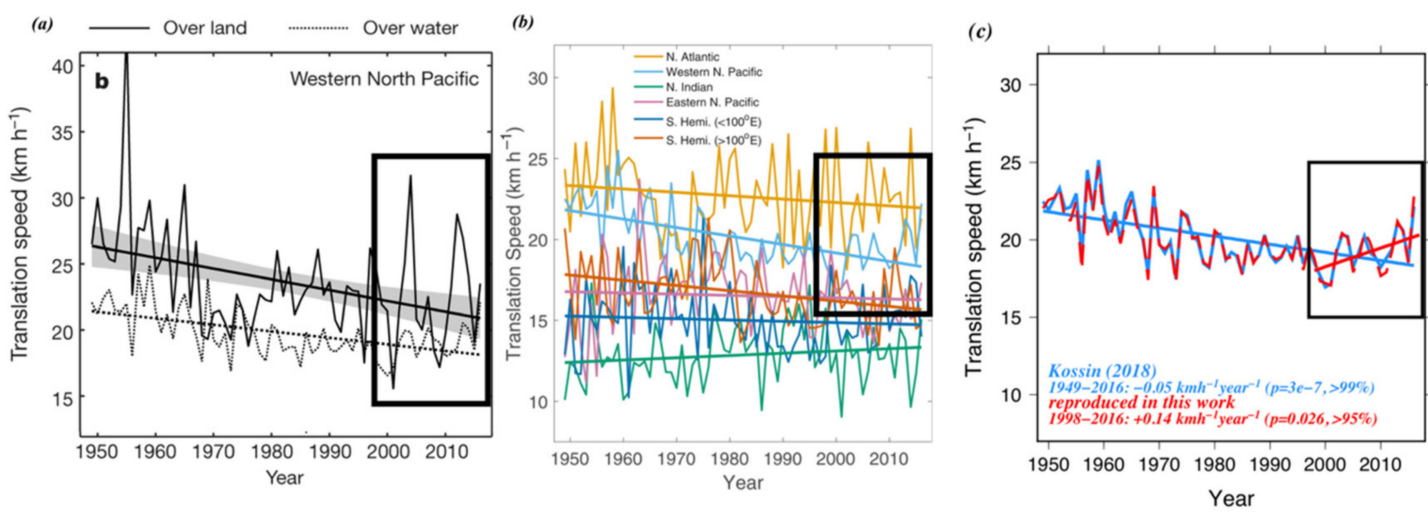

Figure 1. (a) Translation speed in the western North Pacific which is adopted from Figure $3 b$ in Kossin (2018). The black line is over land, while the dashed line is over water. The black box highlights the period from 1998 to 2016 for the increasing translation speed. (b) Adopted from the Extended Data Figure 1 in Kossin (2018) for translation speed in different basins. The black box is the same as in Figure 1a. Notice that the range of the y-axis is different from that shown in Figure 1a. (c) TCs' translation speeds are reproduced in this work. The light blue line was depicted in Figure $1 \mathrm{~b}$ for the western North Pacific. The red line is the reproduced Uh from JTWC's best track archive in the western North Pacific. The blue straight line is the trend from 1949 to 2016. For the updated data, a red straight line is the trend from 1998 to 2017. Black box is the same as in Figure 1a.

After successful reproduction of Kossin's trend (Figure 1c), we proceeded to check the Uh trends over Asian regions for the TC season (from July to October). Three test regions are the TC main development region (WNP MDR, Figure 2), the East China Sea (ECS), and the South China Sea (SCS). Uh in the WNP MDR has a narrower distribution (between 4 to $6 \mathrm{~ms}^{-1}$ ) (Figure 3a). On average, TCs in the SCS traveled at a speed of $3.12 \mathrm{~ms}^{-1}$ in 1998 . However, they sped up to $4.80 \mathrm{~ms}^{-1}$ in 2017 . The rate of increase was over 50\% compared to 1998 (Figure 3b). Uh in the ECS covers a wide range from $2.49 \mathrm{~ms}^{-1}$ to $7.56 \mathrm{~ms}^{-1}$ (Figure 3c) and varied a lot inter-annually. Among the three regions being observed, the trend of Uh was lowest in the WNP MDR at $+0.0147 \mathrm{~ms}^{-1}$ year $^{-1}$ (Figure 3a). The ECS had the second largest increasing trend at $+0.053 \mathrm{~ms}^{-1}$ year $^{-1}$ (Figure 3c). Both trends in the WNP MDR and ECS are not statistically significant. We found evidence of Uh increasing over the SCS at $+0.077 \mathrm{~ms}^{-1}$ year $^{-1}$ with statistical significance $(p=0.006,>99 \%)$. The increasing trend in the SCS was five times greater than in the WNP MDR (Figure 3a) for the same period. The trends over the WNP MDR and ECS are much weaker and did not pass statistical significance tests. Thus, we focused our subsequent explorations over the SCS.

\subsection{Observations in the SCS: TC Intensity Change and Pre-TC Ocean Conditions}

Surrounded by many densely-populated Asian countries, the SCS is important in many ways (social-economical, ecological, military, and more) (Figure 2). It is a marginal sea between the WNP 
and the Asian continent. The connections to surrounding seas are normally shallow, with the exception of the Luzon Strait, which connects to the Phillipe Sea [63]. Due to the geostrophic balance with the western boundary current, Kuroshio, the thermocline has a sharp gradient through the Luzon Strait [8]. Compared to the WNP, the mixed layer was thinner and the thermocline was shallower in the SCS.

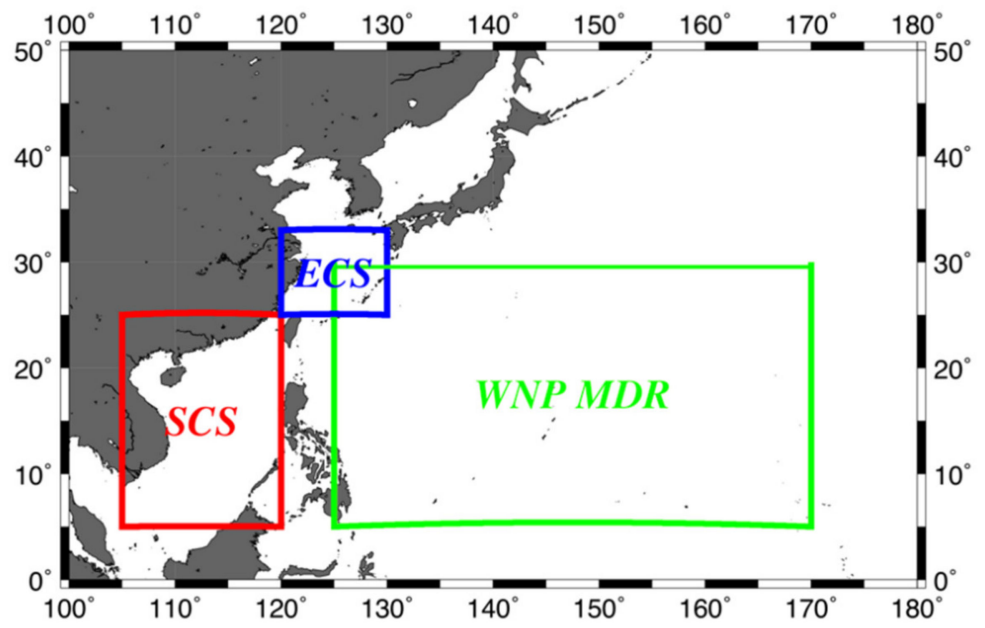

Figure 2. Regions for data selection. TC points in every 6-hour period inside the big map $\left(100-180^{\circ} \mathrm{E}\right.$, $0-50^{\circ} \mathrm{N}$ ) were used to reproduce Uh (red line in Figure 1c) in Extended Data Figure 1 of Kossin (2018). The green box represents the main development region in the western North Pacific (WNP MDR, $\left.125-170^{\circ} \mathrm{E}, 5-30^{\circ} \mathrm{N}\right)$. The Uh results can be found in Figure 3a. The red box is the area of the South China Sea (SCS, $105-120^{\circ} \mathrm{E}, 5-25^{\circ} \mathrm{N}$ ), the Uh result is in Figure $3 \mathrm{~b}$. The blue box is for the East China Sea (ECS, $\left.120-130^{\circ} \mathrm{E}, 25-33^{\circ} \mathrm{N}\right)$, the Uh result is in Figure $3 \mathrm{c}$.
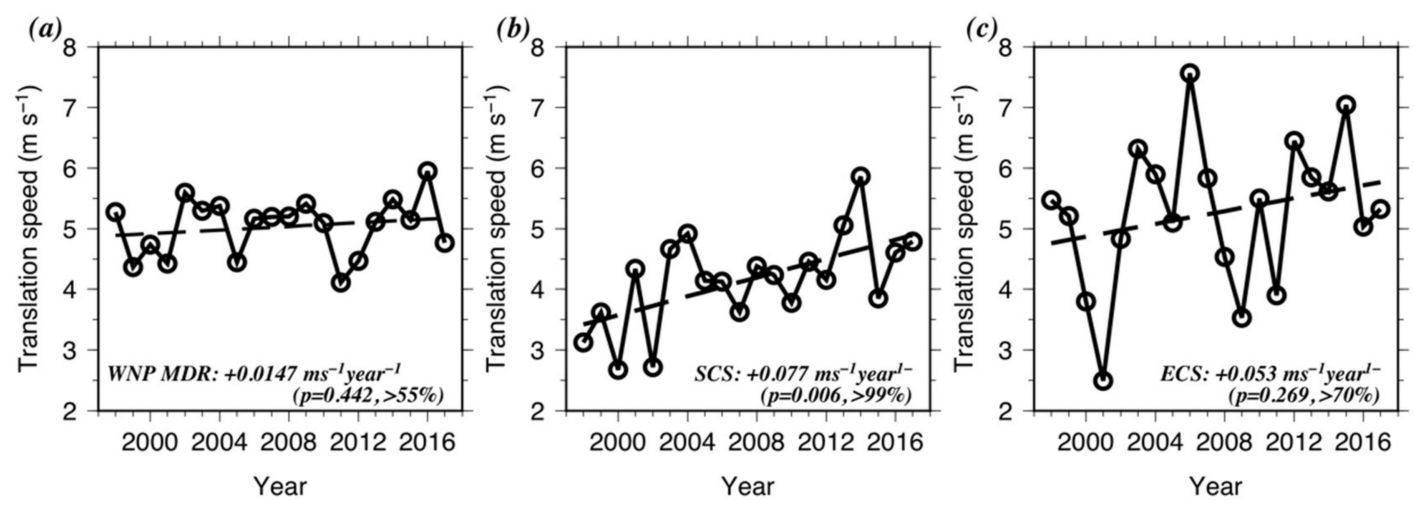

Figure 3. Uh with unit of $\mathrm{ms}^{-1}$ in the (a) WNP MDR, (b) SCS, and (c) ECS, the corresponding area can be found in Figure 2. The trend for each time series is also shown.

Typhoons over the SCS $[5,6,8,9,29,36,37,54]$ strongly impact the surrounding populations in the Philippines, Taiwan, Hong Kong, Macao, coastal China, Vietnam, and other neighboring regions. If the translation speed of these typhoons over the SCS increases, then, in the context of TC-ocean interaction, there is a possibility to favor TC intensity increase. This is because a TC's self-induced cooling is smaller under a faster Uh [4] and more air-sea enthalpy fluxes [11] can be made available for TC intensification [14]. Given the evident Uh increasing trend found in the SCS since 1998, we examine this possibility.

Figure 4 illustrates the TC-season average TC intensity (in 1-minute maximum sustained wind speed) time series in the SCS. As can be seen in the chart, despite some interannual variability, an increasing trend at $+0.356 \mathrm{~ms}^{-1}$ year $^{-1}$, with statistical significance $(p=0.027,>95 \%)$ is found. Whether this increase in TC intensity is associated with an increase in Uh needs to be further examined. There 
can be different possibilities associated with such an increase, including atmospheric and oceanic factors. Each of the related factors will be examined below. Using ORAS4 reanalysis data, we examined three TC-related oceanic parameters, i.e., SST, D26, and tropical cyclone heat potential (TCHP, i.e., depth-integrated upper ocean heat content (UOHC) from sea surface down to D26) $[41,42,44-46,60,64]$. All the oceanic parameters were obtained in grids with depth over $200 \mathrm{~m}$. SST was obtained directly from the ORAS4 temperature at the first level. D26 was obtained via interpolation from the ORAS4 thermal profile. TCHP (or UOHC) is calculated below.

$$
\mathrm{TCHP}=C_{p} \sum_{0}^{Z_{26}} \rho_{i}\left(T_{i}-26\right) \Delta z_{i}
$$

where $C_{p}$ is the specific heat of water at constant pressure, $\rho_{i}$ is the density at the $i$-th level, $T_{i}$ is the temperature at the $i$-th level, and $\Delta z_{i}$ is the thickness of the $i$-th level. SST, D26, and TCHP were averaged within the research domain $\left(105-120^{\circ} \mathrm{E}, 5-25^{\circ} \mathrm{N}\right)$ and typhoon season (July to October).

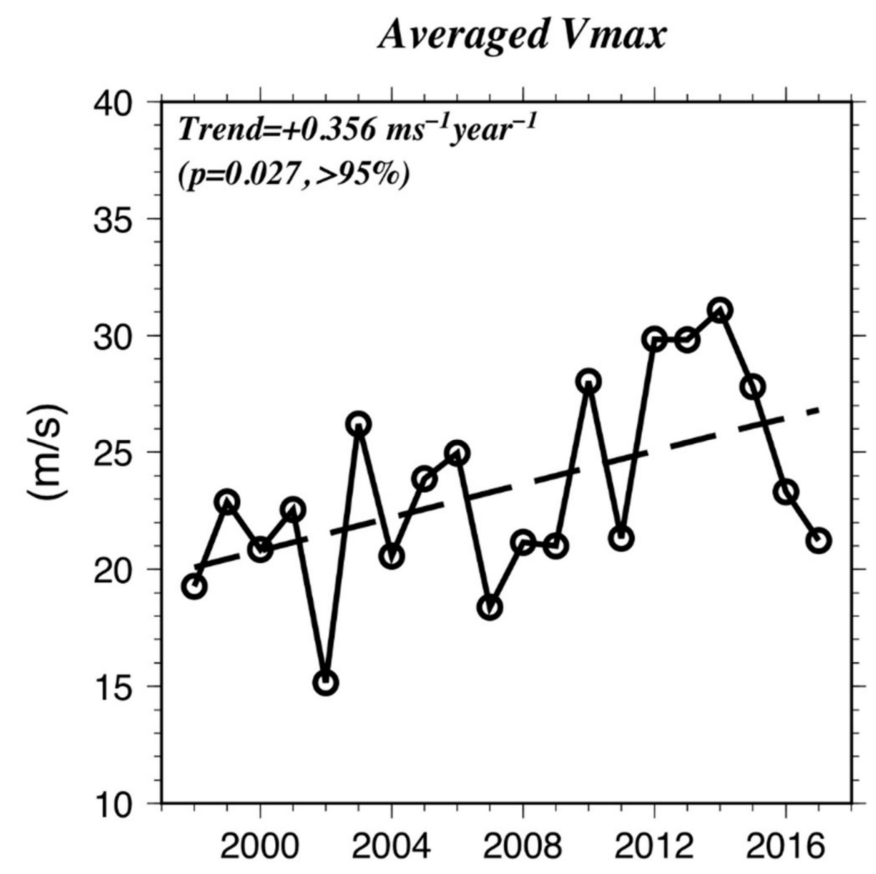

Figure 4. TC season (JASO) average of 1-min maximum sustained wind in the SCS. The average 6-hr TC point count in the TC season (JASO) in the SCS is around 89.

As in Figure 5a, SST in the SCS had no significant trends over the past 20 years. The 20-year average was $29.17^{\circ} \mathrm{C}$ for the typhoon season and SST varied with little amplitude. The highest SST was $30.08^{\circ} \mathrm{C}$ in 1998 and the lowest was $28.78^{\circ} \mathrm{C}$ in 2012 . The difference did not exceed $1.5^{\circ} \mathrm{C}$. There was no significant trend in D26 and the 20-year average of D26 was $\sim 60.75 \mathrm{~m}$ (Figure $5 \mathrm{~b}$ ). The deepest D26 was $66.21 \mathrm{~m}$ in 2010 and the shallowest was $56.06 \mathrm{~m}$ in 2011. Similarly, for TCHP (or UOHC), no trend was observed and the 20-year average of TCHP is $\sim 64.86 \mathrm{kJcm}^{-2}$. Therefore, no significant trend was observed for any of the three parameters, which is consistent with the results in Chiang et al. (2018) [65]. Thus, it is unlikely that the observed increase in TC intensity is associated with these small changes in oceanic parameters. 

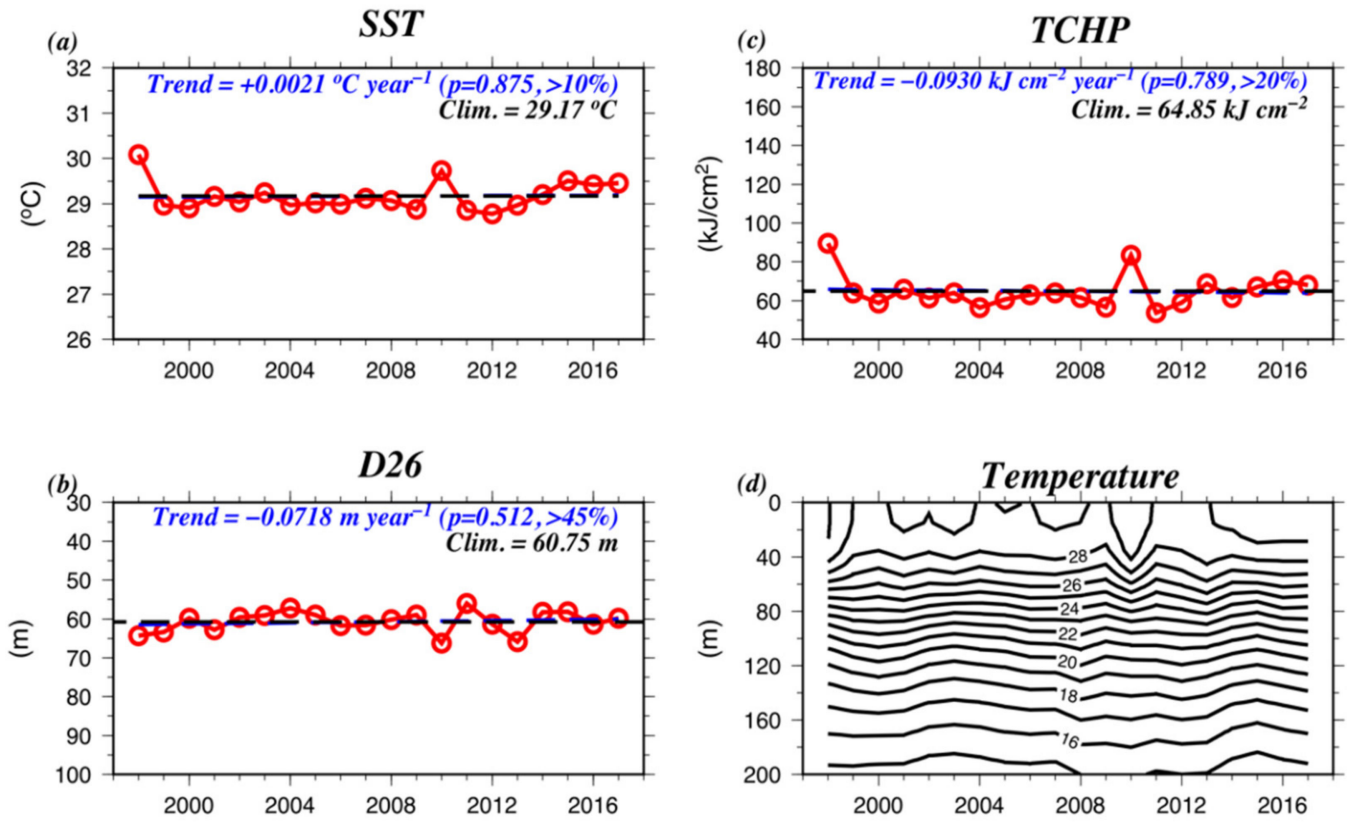

Figure 5. Pre-TC oceanic conditions were evaluated from 1998 to 2017 using the Ocean ReAnalysis System 4 (ORAS4) from ECMWF. The different parameters include: (a) sea surface temperature (SST), (b) depth of $26^{\circ} \mathrm{C}$ (D26), (c) tropical cyclone heat potential (TCHP), and (d) upper ocean profile. The contours are labeled every $2{ }^{\circ} \mathrm{C}$.

\subsection{Numerical Simulations Using the Price (2009) Td Model}

We then examined the possibility of associating the observed Uh increase (Figure 3b) with the TC intensity increase (Figure 4). Using the Price (2009) Td model, we conducted three sets of numerical experiments to estimate the TC-induced ocean cooling effect. The first experiment (grey line in Figure 6) is to fix Uh at its 1998 level (i.e., a reference scenario if there is no increase in Uh), the second experiment (red line in Figure 6) is to fix Vmax at its 1998 level (i.e., a reference scenario if there is no increase in Vmax), and the third experiment (blue line in Figure 6) is based on the observed Uh (i.e., increase in Uh from 1998 to 2017, in Figure 3b) and the observed Vmax (Figure 4). Besides the difference in Uh and Vmax, all other inputs are the same for the three experiments (i.e., pre-TC UOTS profiles from Figure 5d and RMW). Figure 6a depicts pre-TC SST (i.e., same as Figure 5a) and the during-TC SST (i.e., estimated from Price (2009) Td model). The TC-induced cooling results (i.e., during-TC SST minus pre-TC SST) are depicted in Figure 6b. For Experiment 1 (no observed Uh changes in time), TC-induced cooling typically fluctuated between approximately -0.2 and $-1.3{ }^{\circ} \mathrm{C}$, with a statistically significant trend of $-0.0242{ }^{\circ} \mathrm{C}_{\text {year }}{ }^{-1}$ (grey dashed line in Figure $6 \mathrm{~b}$ ). This is reasonable because Uh still maintains the same slow level as it did in 1998. If there is no Uh change in time, cooling increases in time are primarily dependent on the increase in Vmax. This result supports our observation. Since Uh increases over time as from observation, the cooling effect is weakened in Experiment 3 compared to Experiment 1 (blue line in Figure 6). In other words, the difference between Experiment 1 and 3 is only the difference in Uh. Because Uh in Experiment 3 is increasing over time, the cooling effect is smaller in Experiment 3 than in Experiment 1. Experiment 3 also shows the offsetting effects between Vmax increase and Uh increase (i.e., although Vmax increase may increase cooling effect, it is offset by the Uh increase). Experiment 2 is an additional reference experiment simulating the situation if there is no Vmax change. It also supports the results, because if Vmax is fixed, as it was in 1998, only Uh increases with time and cooling reductions with time will be detected. 

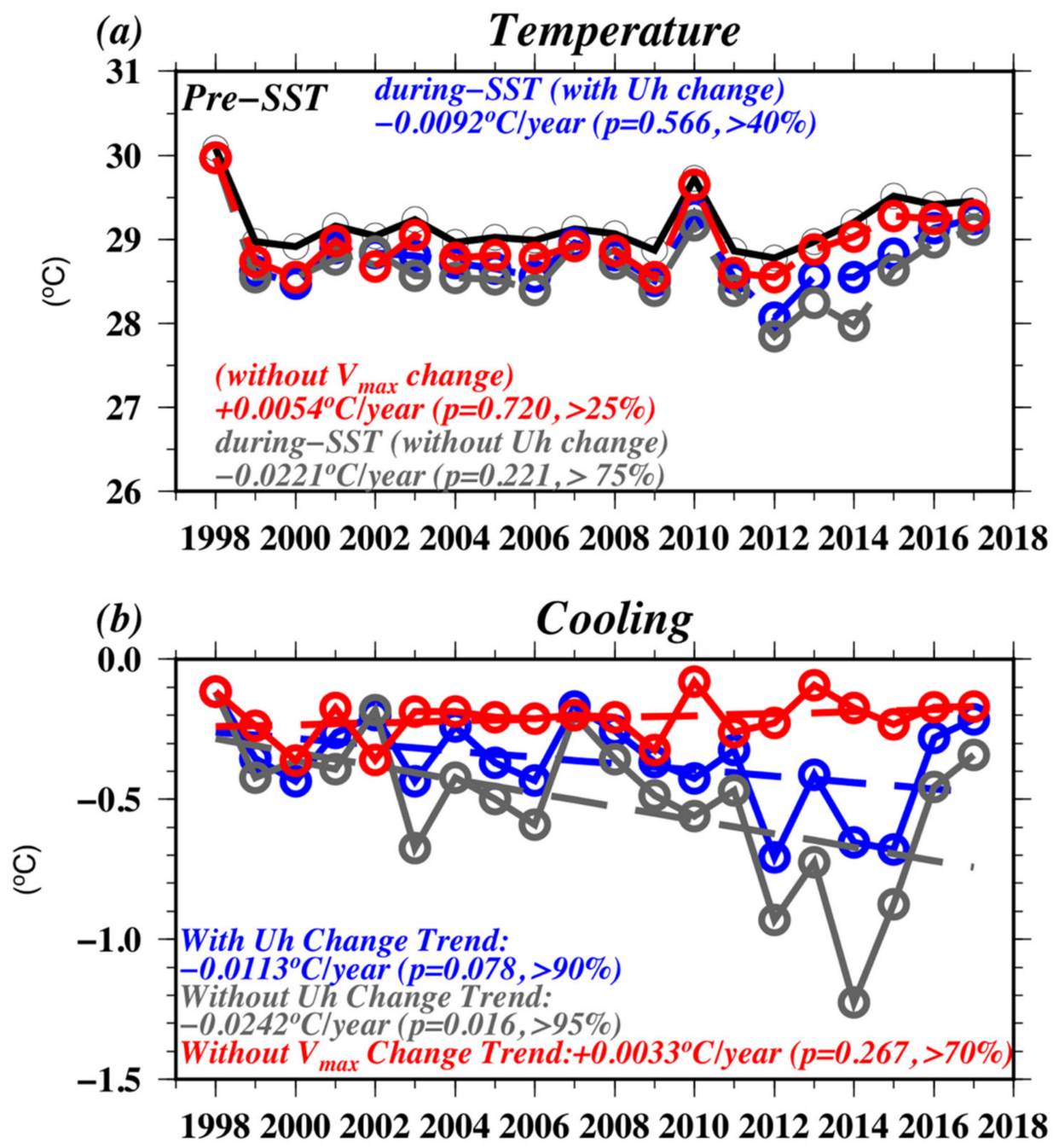

Figure 6. (a) Pre-TC SST (black line) and $\mathrm{T}_{\text {mix }}$ estimated using the Price (2009) Td model. The grey line is for without Uh change (fixed at 1998 level), the red line is for without Vmax change (fixed at 1998 level), and the blue line is for observed Uh and Vmax change. (b) TC-induced cooling ( $\mathrm{T}_{\text {mix }}$ minus pre-TC SST). The grey line is for without Uh change (fixed at 1998 level), the red line is for without Vmax change (fixed at 1998 level), and the blue line is for observed Uh and Vmax change.

\subsection{Air-Sea Flux Estimation}

As in Lin et al. (2013) [15] and above, the during-TC SST is the actual SST "felt" by a TC during TC-ocean interaction. The during-TC SST is different from the pre-TC SST because it includes the TC-ocean coupling (cooling) effect (Figure 6a), which plays an important role in the air-sea enthalpy (sensible and latent) heat flux supply for TC intensification [11,13,15-17]. Using the during-TC SST $\left(T_{\text {mix }}\right)$ from Figure 6a and the atmospheric data (i.e., $T_{a}$ and $q_{a}$ ) in corresponded grids as calculated for Figure 5, we can calculate the air-sea enthalpy flux for the all three experiments using Equation (5). Figure 7 depicts the results. In Experiment 3 (blue line, i.e., Uh and Vmax increase as observed), there was more air-sea enthalpy flux supply for TC intensification, as compared to Experiment 1 (i.e., fixed Uh at 1998 level). The trend for Experiment 1 (grey line in Figure 7) is $+2.890 \mathrm{Wm}^{-2}$ year $^{-1}(p=0.290$, $>70 \%$ ). The trend for Experiment 3 (blue line in Figure 7) is $+5.158 \mathrm{Wm}^{-2}$ year $^{-1}(p=0.093,>90 \%)$, which is higher and statistically more significant than the trend found in Experiment 1 . This suggests that the increase in TC translation speed reduces the TC-induced ocean cooling effect. Therefore, the corresponding flux supply is higher to support TC intensification. The enthalpy flux difference between Experiment 1 and 3 (grey and blue line in Figure 7) is clearer when Uh is faster than $4.5 \mathrm{~ms}^{-1}$ 
(e.g., in 2013 and 2014). Although Experiment 2 (without Vmax change with time) has the lowest level of TC-induced cooling, its corresponding enthalpy flux is not high. This is because, when calculating enthalpy flux, the TC's wind speed is also involved in Equation (5). Because there was no wind increase, the production of flux from the wind increase contribution is absent. This also shows that stronger TCs (higher wind speed, W) produce more enthalpy flux, which can be seen as a self-intensified effect. Combined with the TC's increasing Uh and intensity (blue line in Figure 7), the available enthalpy flux increases with a trend of $+5.158 \mathrm{Wm}^{-2} \mathrm{year}^{-1}$.

\section{Enthalpy Flux}

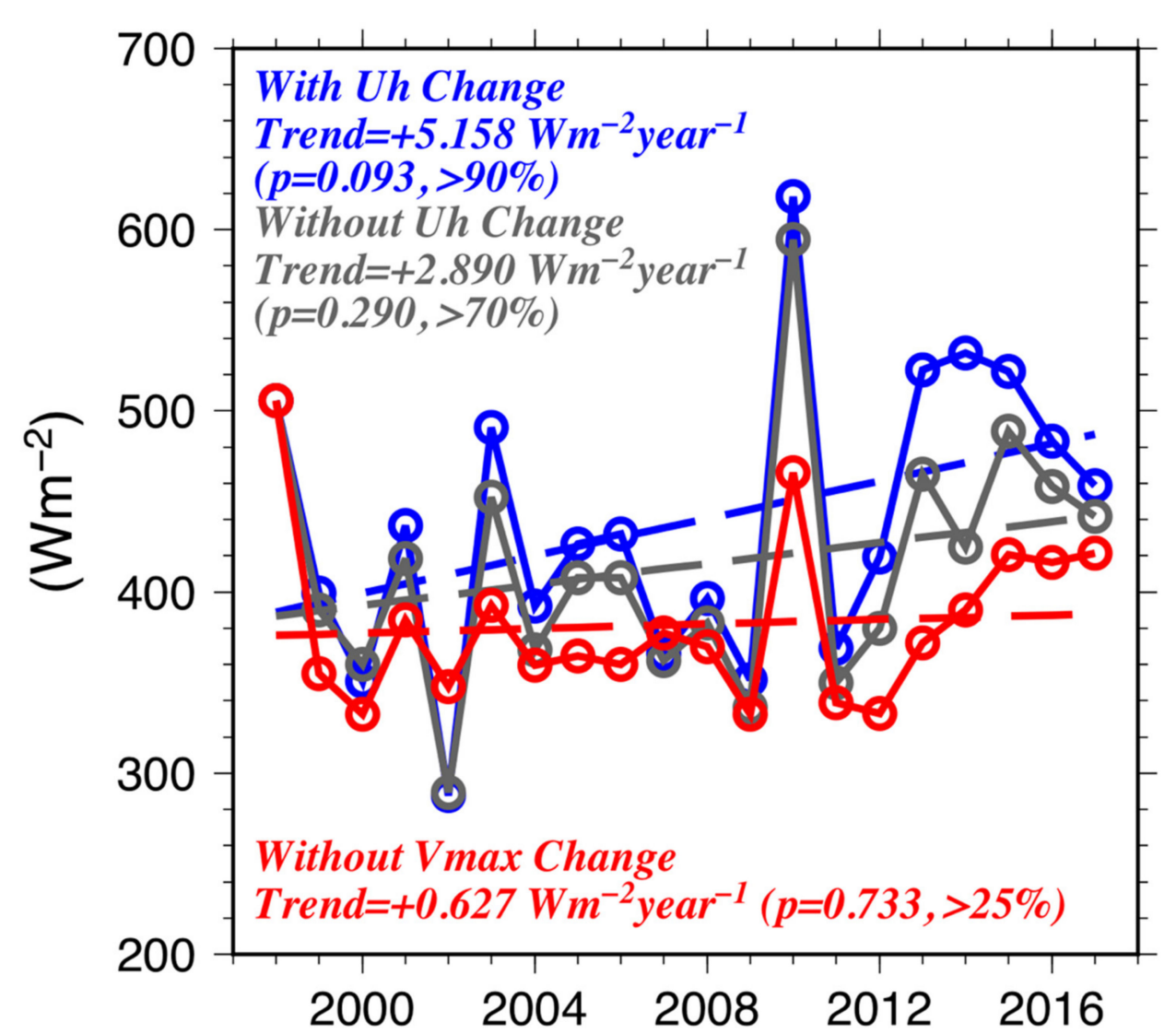

Figure 7. Enthalpy (sensible and latent heat) flux estimated with the $\mathrm{T}_{\mathrm{mix}}$ results of three experiments in Figure 6a. The grey line is for without Uh change (fixed at 1998 level), the red line is for without Vmax change (fixed at 1998 level), and the blue line is for with observed Uh and Vmax change

\subsection{Atmospheric Vertical Wind Shear}

After conducting all the ocean and Uh analysis, it was necessary to examine atmospheric vertical wind shear (VWS), as TC intensification is also influenced by VWS [12,61,62]. As shown in Figure 8, VWS varied interannually over the past 20 years, but without a statistically significant trend. In addition, there was no observable relationship between VWS and TC intensity during this period. This suggests that VWS is unlikely to contribute to the observed increase in TC intensity in Figure 4. 


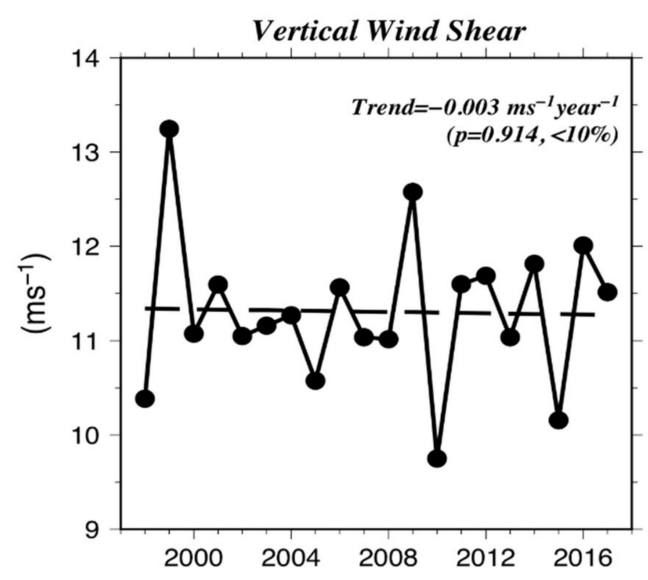

Figure 8. TC season (JASO) average of vertical wind shear (VWS) in the SCS.

\section{Discussion and Conclusions}

TC intensity is influenced by multiple factors, including the well-known primary factors such as SST, D26, UOHC, and atmospheric vertical wind shear (VWS). TC translation speed (Uh) is a possible secondary factor and is thus the motivation for examining the possible connection. Under most situations, the impact from this possible secondary factor is obscured by primary factors. Only when the primary factors have no trends (as in this research) there is a chance to observe the possible influence of Uh. Therefore, in theory, it is possible for Uh to impact TC intensity via the TC-ocean interaction pathway (i.e., the faster the Uh, the lower the TC-induced ocean cooling effect, the more the air-sea enthalpy for intensification). In reality, such a real-world example is rare. The period from 1998 to 2017 was a suitable timeframe to examine this possibility since the primary factors during this period have no trends (Figures 5 and 8). Also, 1998 was a meaningful year for the WNP in the climate context, as it was the year when the multi-decadal PDO (Pacific decadal oscillation) changed from the warm phase to the cold phase [23-25]. Therefore, starting from 1998 ensured that all analyses were performed within the same multi-decadal phase without introducing further complications to obscure the already difficult to observe signal.

During the last two decades, TC translation speed was found to increase evidently $\left(+0.077 \mathrm{~ms}^{-1}\right.$ year $\left.^{-1}\right)$ in the TC-season over the SCS with statistical significance. This triggers our interest to explore the possible subsequent impact on TC-ocean interaction and TC intensity. We found that this increase in TC translation speed can reduce the self-induced ocean cooling effect and increases the during-TC SST. The increase in during-TC SST contributes to higher air-sea enthalpy fluxes available for TC intensification, which can contribute to the observed increase in TC intensity in the SCS over the past 20 years. This is further supported by the data acquired from examining other possible factors (i.e., pre-TC ocean condition and VWS). Because pre-TC ocean conditions show little trend in the SCS over the past two decades and little correlation with the increase in TC intensity, it is unlikely that this observed increase occurred because of the little change in ocean pre-condition. Also, because VWS does not show a significant trend in the past two decades, thus the contribution of VWS is not supported. Therefore, an increase in Uh, the associated reduction in the TC's self-induced ocean cooling effect and the consequential increase in air-sea flux supply, is a possible contributor for the observed increase in TC intensity in the SCS. In this work, we examined VWS, pre-TC SST, D26, TCHP, and $\mathrm{Uh}$ and found that $\mathrm{Uh}$ is the most possible contributor to promoting the increasing trend of TC intensity in the past 20 years over the SCS. Here, we found a positive contribution from Uh increase to TC intensity increase in this work. Certainly, TC intensification is a complex process and there may exist other contributing factors for future investigations. We also want to acknowledge that although a linear trend is used in this research, there may exist other possibilities to explain the observed trend [66]. Finally, understanding why TC translation speed has increased (above the SCS) during the past two decades is an intriguing problem awaiting exploration by the atmospheric community. 
Author Contributions: Conceptualization, I-IL. and Y.-T.C.; methodology, I-I L. and Y.-T.C.; software, Y.-T.C. and H.-C.H.; validation, H.-C.H., Y.-C.L., and C.-C.L.; formal analysis, Y.-T.C.; resources, I-I L.; data curation, Y.-T.C., H.-C.H., and I-IL.; writing — original draft preparation, Y.-T.C.; writing—review and editing, I-I L. and Y.-T.C.; visualization, Y.-T.C.; supervision, I-IL.; project administration, I-IL.; funding acquisition, I-IL. All authors have read and agree to the published version of the manuscript.

Funding: This research was funded by Taiwan's Ministry of Science and Technology (MOST) under 108-2111-M-002 -014 -MY2 and 106-2111-M-002 -011 -MY3.

Acknowledgments: The authors would like to thank the anonymous reviewers for their constructive comments.

Conflicts of Interest: The authors declare no conflict of interest.

\section{References}

1. Wang, C.-C.; Kuo, H.-C.; Chen, Y.-H.; Huang, H.-L.; Chung, C.-H.; Tsuboki, K. Effects of asymmetric latent heating on typhoon movement crossing Taiwan: The case of Morakot (2009) with extreme rainfall. J. Atmos. Sci. 2012, 69, 3172-3196. [CrossRef]

2. Kossin, J.P. A global slowdown of tropical-cyclone translation speed. Nature 2018, 558, 104-107. [CrossRef]

3. Sharma, K.K.; Verdon-Kidd, D.C.; Magee, A.D. Decadal variability of tropical cyclogenesis and decay in the southwest Pacific. Int. J. Climatol. 2019. [CrossRef]

4. Price, J.F. Upper ocean responses to a hurricane. J. Phys. Oceanogr. 1981, 11, 23. [CrossRef]

5. Lin, I-I; Liu, W.T.; Wu, C.-C.; Chiang, J.C.H.; Sui, C.-H. Satellite observations of modulation of surface winds by typhoon-induced upper ocean cooling. Geophys. Res. Lett. 2003, 30, 1131. [CrossRef]

6. $\quad$ Lin, I-I; Liu, W.T.; Wu, C.-C.; Wong, G.T.F.; Hu, C.; Chen, Z.; Liang, W.-D.; Yang, Y.; Liu, K.-K. New evidence for enhanced ocean primary production triggered by tropical cyclone. Geophys. Res. Lett. 2003, $30,1718$. [CrossRef]

7. Lin, I-I; Chen, C.-H.; Pun, I.-F.; Liu, W.T.; Wu, C.-C. Warm Ocean Anomaly, Air Sea Fluxes, and the Rapid Intensification of Tropical Cyclone Nargis (2008). Geophys. Res. Lett. 2009, 36, L03817. [CrossRef]

8. Mei, W.; Lien, C.-C.; Lin, I-I; Xie, S.-P. Tropical Cyclone-Induced Ocean Response: A Comparative Study of the South China Sea and Tropical Northwest Pacific. J. Clim. 2015, 28, 5952-5968. [CrossRef]

9. Zhao, X.; Chan, J.C.L. Changes in tropical cyclone intensity with translation speed and mixed-layer depth: Idealized WRF-ROMS coupled model simulations. Q. J. R. Meteorol. Soc. 2017, 143, 152-163. [CrossRef]

10. Price, J.F.; Sanford, T.B.; Forristall, G.Z. Forced Stage Response to a Moving Hurricane. J. Phys. Oceanogr. 1994, 24, 233-260. [CrossRef]

11. Emanuel, K.A. Thermodynamic control of hurricane intensity. Nature 1999, 401, 5. [CrossRef]

12. Emanuel, K.A.; DesAutels, C.; Hollow, C.; Korty, R. Environmental Control of Tropical Cyclone Intensity. J. Atmos. Sci. 2004, 61, 843-858. [CrossRef]

13. Black, P.G.; D’Asaro, E.A.; Drennan, W.M.; French, J.R.; Niiler, P.P.; Sanford, T.B.; Terrill, E.J.; Walsh, E.J.; Zhang, J.A. Air-sea exchange in hurricanes: Synthesis of observations from the coupled boundary layer air-sea transfer experiment. Bull. Am. Meteorol. Soc. 2007, 88, 357-374. [CrossRef]

14. Lin, I-I; Pun, I.-F.; Wu, C.-C. Upper-Ocean Thermal Structure and the Western North Pacific Category 5 Typhoons. Part II: Dependence on Translation Speed. Mon. Weather Rev. 2009, 137, 3744-3757. [CrossRef]

15. Lin, I-I; Black, P.; Price, J.F.; Yang, C.-Y.; Chen, S.S.; Lien, C.-C.; Harr, P.; Chi, N.-H.; Wu, C.-C.; D'Asaro, E.A. An ocean coupling potential intensity index for tropical cyclones. Geophys. Res. Lett. 2013, 40, 1878-1882. [CrossRef]

16. Lin, I-I; Pun, I.-F.; Lien, C.-C. “Category-6” supertyphoon Haiyan in global warming hiatus: Contribution from subsurface ocean warming. Geophys. Res. Lett. 2014, 41, 8547-8553. [CrossRef]

17. D'Asaro, E.A.; Black, P.G.; Centurioni, L.R.; Chang, Y.-T.; Chen, S.S.; Foster, R.C.; Graber, H.C.; Harr, P.; Hormann, V.; Lien, R.-C.; et al. Impact of Typhoons on the Ocean in the Pacific. Bull. Am. Meteorol. Soc. 2014, 95, 1405-1418. [CrossRef]

18. Huang, H.-C.; Boucharel, J.; Lin, I-I; Jin, F.-F.; Lien, C.-C.; Pun, I.-F. Air-sea fluxes for Hurricane Patricia (2015): Comparison with supertyphoon Haiyan (2013) and under different ENSO conditions. J. Geophys. Res. Oceans 2017, 122, 6076-6089. [CrossRef]

19. Chu, J.-H.; Sampson, C.R.; Levin, A.S.; Fukada, E. The Joint Typhoon Warning Center Tropical Cyclone Best Tracks 1945-2000; Joint Typhoon Warning Center: Pearl Harbor, HI, USA, 2002. 
20. Emanuel, K.A.; Caroff, P.; Delgado, S.; Guard, C.C.; Guishard, M.; Hennon, C.; Knaff, J.; Knapp, K.R.; Kossin, J.; Schreck, C.; et al. On the desirability and feasibility of a global re-analysis of tropical cyclones. Bull. Am. Meteorol. Soc. 2018, 99, 427-429. [CrossRef]

21. Moon, I.-J.; Kim, S.-H.; Chan, J.C.L. Climate change and tropical cyclone trend. Nature 2019, 570, E3-E5. [CrossRef]

22. Lanzante, J.R. Uncertainties in tropical-cyclone translation speed. Nature 2019, 570, E6-E9. [CrossRef] [PubMed]

23. Hu, C.; Zhang, C.; Yang, S.; Chen, D.; He, S. Perspective on the northwestward shift of autumn tropical cyclogenesis locations over the western North Pacific from shifting. Clim. Dyn. 2018, 51, 2455-2465. [CrossRef]

24. Zhang, C.; Hu, C.; Huang, G. Perspective on Landfalling Frequency and Genesis Location Variations of Southern China Typhoon During Peak Summer. Geophys. Res. Lett. 2019, 46, 6830-6838. [CrossRef]

25. Zhao, H.; Wang, C. On the relationship between ENSO and tropical cyclones in the western North Pacific during the boreal summer. Clim. Dyn. 2019, 52, 275-288. [CrossRef]

26. Chan, J.C.L. Decadal variations of intense typhoon occurrence in the western North Pacific. Proc. R. Soc. 2008, 464, 249-272. [CrossRef]

27. Liu, K.S.; Chan, J.C.L. Interdecadal Variability of Western North Pacific Tropical Cyclone Tracks. J. Clim. 2008, 21, 4464-4476. [CrossRef]

28. Wu, C.-R.; Chang, Y.-L.; Oey, L.Y.; Chang, C.-W.J.; Hsin, Y.-C. Air-sea interaction between tropical cyclone Nari and Kuroshio. Geophys. Res. Lett. 2008, 35, L12605. [CrossRef]

29. Chiang, T.-L.; Wu, C.-R.; Oey, L.-Y. Typhoon Kai-Tak: An Ocean's Perfect Storm. J. Phys. Oceanogr. 2011, 41, 221-233. [CrossRef]

30. Pun, I.-F.; Chang, Y.-T.; Lin, I-I; Tang, T.-Y.; Lien, R.-C. Typhoon-Ocean Interaction in the Western North Pacific, Part 2. Oceanography 2011, 24, 32-41. [CrossRef]

31. Guan, S.; Zhao, W.; Huthnance, J.M.; Tian, J.; Wang, J. Observed upper ocean response to typhoon Megi (2010) in the Northern South China Sea. J. Geophys. Res. Oceans 2014, 119, 3134-3157. [CrossRef]

32. Ko, D.S.; Chao, S.-Y.; Wu, C.-C.; Lin, I-I. Impacts of typhoon Megi (2010) on the South China Sea. J. Geophys. Res. Oceans 2014, 119, 4474-4489. [CrossRef]

33. Yang, L.; Du, Y.; Wang, D.; Wang, C.; Wang, X. Impact of intraseasonal oscillation on the tropical cyclone track in the South China Sea. Clim. Dyn. 2015, 44, 1505-1519. [CrossRef]

34. Ko, D.S.; Chao, S.-Y.; Wu, C.-C.; Lin, I-I; Jan, S. Impacts of tides and Typhoon Fanapi (2010) on seas around Taiwan. Terr. Atmos. Ocean. Sci. 2016, 27, 261-280. [CrossRef]

35. Wu, C.-C.; Tu, W.-T.; Pun, I.-F.; Lin, I-I; Peng, M.S. Tropical cyclone-ocean interaction in Typhoon Megi (2010) - A synergy study based on ITOP observations and atmosphere-ocean coupled model simulations. J. Geophys. Res. 2016, 121, 153-167. [CrossRef]

36. Sun, J.; Oey, L.; Xu, F.-X.; Lin, Y.-C. Sea level rise, surface warming, and the weakened buffering ability of South China Sea to strong typhoons in recent decades. Sci. Rep. 2017, 7, 7418. [CrossRef] [PubMed]

37. Pun, I.-F.; Chan, J.C.L.; Lin, I-I; Chan, K.T.F.; Price, J.F.; Ko, D.S.; Lien, C.-C.; Wu, Y.-L.; Huang, H.-C. Rapid Intensification of Typhoon Hato (2017) over Shallow Water. Sustainability 2019, 11, 3709. [CrossRef]

38. Xiao, F.; Wang, D.; Zeng, L.; Yan, Q.; Wen, L. Contrasting changes in the sea surface temperature and upper ocean heat content in the South China Sea during recent decades. Clim. Dyn. 2019, 53, 1597-1612. [CrossRef]

39. Yang, Y.-J.; Chang, M.-H.; Hsieh, C.-Y.; Chang, H.-I.; Jan, S.; Wei, C.-L. The role of enhanced velocity shears in rapid ocean cooling during Super Typhoon Nepartak 2016. Nat. Commun. 2019, 10, 1627. [CrossRef]

40. Balmaseda, M.A.; Mogensen, K.; Weaver, A.T. Evaluation of the ECMWF ocean reanalysis system ORAS4. Q. J. R. Meteorol. Soc. 2013, 139, 1132-1161. [CrossRef]

41. Lin, I-I; Wu, C.-C.; Emanuel, K.; Lee, I.-H.; Wu, C.-R.; Pun, I.-F. The interaction of Supertyphoon Maemi (2003) with a warm ocean eddy. Mon. Weather Rev. 2005, 133, 2635-2649. [CrossRef]

42. Lin, I-I; Wu, C.-C.; Pun, I.-F.; Ko, D.S. Upper-ocean thermal structure and the western North Pacific category 5 typhoons. Part I: Ocean features and the category 5 typhoons' intensification. Mon. Weather Rev. 2008, 136, 3288-3306. [CrossRef]

43. D'Asaro, E.A.; Sanford, T.B.; Niiler, P.P.; Terrill, E.J. Cold wake of Hurricane Frances. Geophys. Res. Lett. 2007, 34, L15609. [CrossRef]

44. Shay, L.K.; Goni, G.J.; Black, P.G. Effects of a warm oceanic feature on Hurricane Opal. Mon. Weather Rev. 2000, 128, 1366-1383. [CrossRef] 
45. Goni, G.J.; DeMaria, M.; Knaff, J.; Sampson, C.; Ginis, I.; Bringas, F.; Mavume, A.; Lauer, C.; Lin, I-I; Ali, M.M.; et al. Applications of Satellite-Derived Ocean Measurements to Tropical Cyclone Intensity Forecasting. Oceanography 2009, 22, 190-197. [CrossRef]

46. Jaimes, B.; Shay, L.K.; Brewster, J.K. Observed air-sea interactions in tropical cyclone Issac over Loop Current mesoscale eddy features. Dyn. Atmos. Oceans 2016, 76, 306-324. [CrossRef]

47. Pun, I.-F.; Lin, I-I; Lo, M.-H. Recent Increase in High Tropical Cyclone Heat Potential Area in the Western North Pacific Ocean. Geophys. Res. Lett. 2013, 40, 4680-4684. [CrossRef]

48. Pun, I.-F.; Lin, I-I; Lien, C.-C.; Wu, C.-C. Influence of the Size of Supertyphoon Megi (2010) on SST Cooling. Mon. Weather Rev. 2018, 146, 661-677. [CrossRef]

49. Walker, N.D.; Leben, R.R.; Pilley, C.T.; Shannon, M.; Herndon, D.C.; Pun, I.-F.; Lin, I-I; Gentemann, C.L. Slow translation speed causes rapid collapse of northeast Pacific Hurricane Kenneth over cold core eddy. Geophys. Res. Lett. 2014, 41, 7595-7601. [CrossRef]

50. Huang, P.; Lin, I-I; Chou, C.; Huang, R.-H. Change in ocean subsurface environment to suppress tropical cyclone intensification under global warming. Nat. Commun. 2015, 6, 7188. [CrossRef]

51. Zheng, Z.-W.; Lin, I-I; Wang, B.; Huang, H.-C.; Chen, C.-H. A long neglected damper in the El Nino-Typhoon Relationship: A ‘Gaia-Like' Process. Sci. Rep. 2015, 5, 11103. [CrossRef]

52. Lin, I-I; Goni, G.J.; Knaff, J.; Forbes, C.; Ali, M.M. Ocean Heat Content for Tropical Cyclone Intensity Forecasting and Its Impact on Storm Surge. Nat. Hazards 2013, 66, 1481-1500. [CrossRef]

53. Pun, I-F.; Lin, I-I; Wu, C.-R.; Ko, D.-S.; Liu, W.-T. Validation and Application of Altimetry-derived Upper Ocean Thermal Structure in the Western North Pacific Ocean for Typhoon Intensity Forecast. IEEE Trans. Geosci. Remote. Sens. 2007, 45, 1616-1630. [CrossRef]

54. Ma, Z.; Fei, J.; Liu, L.; Huang, X.; Cheng, X. Effects of the cold core eddy on tropical cyclone intensity and structure under idealized air-sea interaction conditions. Mon. Weather Rev. 2013, 141, 1285-1303. [CrossRef]

55. Tseng, Y.-H.; Jan, S.; Dietrich, D.E.; Lin, I-I; Chang, Y.-T.; Tang, T.Y. Modeled Oceanic Response and sea surface cooling to Typhoon Kai-Tak. Terr. Atmos. Ocean. Sci. 2010, 21, 85-98. [CrossRef]

56. Samson, G.; Giordani, H.; Caniaux, G. Numerical investigation of an oceanic resonant regime induced by hurricane winds. Ocean Dyn. 2009, 59, 565-586. [CrossRef]

57. Chen, S.; Elsberry, R.L.; Harr, P.A. Modeling Interaction of a Tropical Cyclone with Its Cold Wake. J. Atmos. Sci. 2017, 74, 3981-4001. [CrossRef]

58. Price, J.F. Metrics of hurricane-ocean interaction: Vertically-integrated or vertically-averaged ocean temperature? Ocean Sci. 2009, 5, 351-368. [CrossRef]

59. Price, J.F.; Weller, R.A.; Pinkel, R. Diurnal Cycling: Observations and Models of the upper ocean responses to diurnal heating, cooling, and wind mixing. J. Geophys. Res. Oceans 1986, 91, 8411-8427. [CrossRef]

60. Gray, W.M. Hurricanes: Their Formation Structure and likely role in the Tropical Circulation. In Meteorology over the Tropical Oceans; Shaw, D.B., Ed.; Royal Meteorological Society: Bracknell, UK, 1979; pp. 155-218.

61. Frank, W.M.; Ritchie, E.A. Effects of vertical wind shear on the intensity and structure of numerically simulated hurricanes. Mon. Weather Rev. 2001, 129, 2249-2269. [CrossRef]

62. Lin, I-I; Chan, J.C.L. Recent decrease in typhoon destructive potential and global warming implications. Nat. Commun. 2015, 6, 1-8. [CrossRef]

63. Chang, Y.-T.; Hsu, W.-L.; Tai, J.-H.; Tang, T.Y.; Chang, M.-H.; Chao, S.-Y. Cold deep water in the South China Sea. J. Oceanogr. 2010, 66, 183-190. [CrossRef]

64. Leipper, D.F.; Volgenau, L.D. Hurricane Heat Potential of the Gulf of Mexico. J. Phys. Oceanogr. 1972, 2, 218-224. [CrossRef]

65. Chiang, T.-L.; Hsin, Y.-C.; Wu, C.-R. Multidecadal Changes of Upper-Ocean Thermal Conditions in the Tropical Northwest Pacific Ocean versus South China Sea during 1960-2015. J. Clim. 2018, 31, 3999-4016. [CrossRef]

66. Lin, I-I; Camargo, S.; Patricola, C.; Boucharel, J.; Chand, S.; Klotzbach, P.; Chan, J.; Wang, B.; Chang, P.; Li, T.; et al. ENSO and Tropical Cyclones. In AGU monograph for the AGU Centennial-ENSO in a Changing Climate; Wiley: Hoboken, NJ, USA, 2020.

(C) 2020 by the authors. Licensee MDPI, Basel, Switzerland. This article is an open access article distributed under the terms and conditions of the Creative Commons Attribution (CC BY) license (http://creativecommons.org/licenses/by/4.0/). 